\section{Shade Effect on Growth and Productivity of Tomato and Chili Pepper}

\author{
Joseph Masabni ${ }^{1}$, Youping Sun ${ }^{2,4}$, Genhua $\mathrm{Niu}^{2,4}$, \\ and Priscilla Del Valle ${ }^{3}$
}

AdDitional INDEX wORDs. chlorophyll fluorescence, fruit yield, heat stress, high light intensity, leaf temperature, net photosynthetic rate

Summary. Southern U.S. states such as Texas experience high temperatures and intense solar radiation during the summer production season. Use of shadecloth is common in Spain and other Mediterranean countries and is becoming popular with homeowners or small-acreage farmers in Texas. Little information is available on the applicability of using shadecloth on tomato (Solanum lycopersicum) and chili pepper (Capsicum annumm) in the warm climate of Texas. The effects of two shade nets differing in shading intensity on growth, chlorophyll fluorescence, and photosynthesis of 'Celebrity' tomato and 'Sweet Banana' chili pepper was investigated from May to Aug. 2014. Plants were grown in $50 \%$ shade, $70 \%$ shade, or full sun. Compared with the unshaded control, tomato grown in $\mathbf{5 0 \%}$ shade had similar yield and shoot fresh and dry weight and less photochemical stress. The $50 \%$ shade reduced number and weight of unmarketable tomato fruit. Similar results were obtained with chili pepper except for lower numbers of marketable fruit. The $70 \%$ shade significantly reduced yield parameters of both tomato and chili pepper. Both $50 \%$ and $70 \%$ shadecloth reduced leaf temperatures of tomato and chili pepper with variable results in June and July. Growth index [ (height + width $1+$ width $2) \div 3$ ] of tomato and chili pepper was the highest with $50 \%$ shade, the lowest with full sun, and intermediate with $70 \%$ shade. The maximum net photosynthetic rates $\left(P_{n}\right)$ of tomato determined from a $P_{n}$ to light response curve supported the results on growth and yield. However, the maximum $P_{n}$ of chili pepper was higher in full sun treatment compared with $50 \%$ or $70 \%$ shade. The latter two were almost identical. This one growing season study indicated that shading at $\mathbf{5 0 \%}$ benefits tomato and chili pepper production in west Texas by reducing heat stress; however, a shading percentage below $50 \%$ may be better.

$\mathrm{H}$ igh temperature and light intensity during the summer have a negative effect on plant growth and yield (Lopez-Marin et al., 2012). Excessive light and heat load on leaves is a result of high solar radiation (Lopez-Marin et al., 2011) which severely limits the productivity

This project is supported in part by the U.S. Department of Agriculture National Institute of Food and Agriculture Hatch project TEX 090450 and Texas A\&M AgriLife Research. Priscilla Del Valle and the reported work are supported in part by the National Institute of General Medical Sciences of the National Institutes of Health under Award Number R25GM060424

Any opinions, findings, conclusions, or recommendations expressed in this publication are those of the authors and do not necessarily reflect the view of the funding agencies.

${ }^{1}$ Texas A\&M AgriLife Extension Service, Overton Research and Extension Center, 1710 FM 3053 N, Overton, TX 75684

${ }^{2}$ Texas A\&M AgriLife Research and Extension Center at El Paso, Texas A\&M University System, 1380 A\&M Circle, El Paso, TX 79927

${ }^{3}$ Research Initiative for Science Enhancement Program, El Paso Community College, El Paso, TX 79998

${ }^{4}$ Corresponding author. E-mail: youping.sun@ag. tamu.edu or gniu@ag.tamu.edu. of a crop. Reductions in crop yield are frequently observed under Mediterranean conditions with high levels of solar radiation and low air humidity (Katsoulas and Kittas, 2008). Shading is a popular method to improve plant microclimate in the summer by decreasing leaf temperature and leaf transpiration rate, thus alleviating heat stress (Aberkani et al., 2008). The cultivation area under shade is constantly increasing in Mediterranean countries such as Israel, Morocco, and others (Tanny et al., 2014).
In Texas, commercial tomato production in open field is limited to relatively short periods of favorable temperatures during the spring and early fall. With the advent of high temperatures, usually in June, vegetative vigor and reproductive ability of the plants start to decline with a corresponding blossom abscission and failure of fruit set. Flowering, pollination, and fruit set of tomato are often adversely affected by extreme high temperatures. The optimum temperatures for tomato fruit set are from 18.5 to $26.5^{\circ} \mathrm{C}$ (LeBoeuf, 2004). Chili pepper is primarily cultivated in warm and semiarid regions where high irradiance and temperatures during summer growing seasons are common (Dorji et al., 2005). Therefore, the optimal temperatures for chili pepper may be higher than those for tomato. In other words, chili pepper may be more tolerant than tomato to full sun and high temperatures in Texas.

In southern and western Texas, high temperatures in summer months often exceed $35^{\circ} \mathrm{C}$ and in some days the high temperatures can even reach to $40^{\circ} \mathrm{C}$ and higher. According to our local weather station (El Paso, $\mathrm{TX}$ ), relative humidity during the day can be in the teens and maximum solar radiation can reach $32 \mathrm{MJ} \cdot \mathrm{m}^{-2} \cdot \mathrm{d}^{-1}$, equivalent to $64 \mathrm{~mol} \cdot \mathrm{m}^{-2} \cdot \mathrm{d}^{-1}$ in the 400 to $700 \mathrm{~nm}$ range of the photosynthetically active radiation (PAR). The high temperature and solar radiation lead to high plant temperatures, thus causing heat stress.

Shade screens reduce solar radiation during the day, thus reducing heat stress (Lopez-Marin et al., 2012). Previous studies indicated that shade screens, mostly light shade, led to an increase in productivity and quality of tomato, pear (Pyrus sp.), apple (Malus $\times$ domestica), strawberry (Fragaria $\times$ ananassa), grape (Vitis vinifera), and chili pepper

\begin{tabular}{llll}
\hline $\begin{array}{l}\text { Units } \\
\begin{array}{l}\text { To convert U.S. to SI, } \\
\text { multiply by }\end{array}\end{array}$ & U.S. unit & SI unit & $\begin{array}{l}\text { To convert SI to U.S., } \\
\text { multiply by }\end{array}$ \\
\hline 10 & $\%$ & $\mathrm{~g} \cdot \mathrm{L}^{-1}$ & 0.1 \\
0.3048 & $\mathrm{ft}$ & $\mathrm{m}$ & 3.2808 \\
0.0929 & $\mathrm{ft}^{2}$ & $\mathrm{~m}^{2}$ & 10.7639 \\
3.7854 & $\mathrm{gal}$ & $\mathrm{L}$ & 0.2642 \\
2.54 & inch $(\mathrm{es})$ & $\mathrm{cm}$ & 0.3937 \\
0.4536 & $\mathrm{lb}$ & $\mathrm{kg}$ & 2.2046 \\
4.8824 & $\mathrm{lb} / 1000 \mathrm{ft}^{2}$ & $\mathrm{~g} \cdot \mathrm{m}^{-2}$ & 0.2048 \\
1 & $\mathrm{mmho} / \mathrm{cm}^{-2}$ & $\mathrm{dS} \cdot \mathrm{m}^{-1}$ & 1 \\
28.3495 & $\mathrm{oz}$ & $\mathrm{g}$ & 0.0353 \\
$\left({ }^{\circ} \mathrm{F}-32\right) \div 1.8$ & ${ }^{\circ} \mathrm{F}$ & ${ }^{\circ} \mathrm{C}$ & $\left({ }^{\circ} \mathrm{C} \times 1.8\right)+32$
\end{tabular}


(Rajapakse and Shahak, 2007; Shahak et al., 2008). With temperature reduction under the shade proportional to shade intensity (Kittas et al., 2009), a shade may be necessary to alleviate the heat stress of plants for regions with high solar radiation and temperatures. El-Gizawy et al. (1992) reported that shading (up to $51 \%$ ) significantly increased the number of fruit and total yield of tomato in Egypt and the highest yield was achieved at $35 \%$ shading while heavy shading of $63 \%$ had similar yield to full sun. Nevertheless, too much shade can cause yield reduction in some crops, but no research-based information is available in Texas. The purpose of this research is to quantify the effect of relatively heavy shading intensities $(50 \%$ and $70 \%)$ on the growth, yield, chlorophyll fluorescence $\left(\mathrm{F}_{\mathrm{v}} / \mathrm{F}_{\mathrm{m}}\right)$, and $\mathrm{P}_{\mathrm{n}}$ of tomato and chili pepper in semiarid west Texas. We also quantified microclimate traits underneath the shade structures.

\section{Materials and methods}

Site Description. A field experiment was conducted at Texas A\&M AgriLife Research Center at El Paso (lat. $31^{\circ} 41^{\prime} 48^{\prime \prime} \mathrm{N}$, long. $106^{\circ} 16^{\prime} 54^{\prime \prime} \mathrm{W}$, elevation $1140 \mathrm{~m}$ ). The dominant soil is deep sandy soil according to the soil map of El Paso (U.S. Department of Agriculture, 1971). The analytical results of chemical characteristics of the soil indicated that phosphorus, potassium, calcium, magnesium, and sulfur were above critical levels. Nine $5 \times 20$-ft raised beds were amended with manure at $292 \mathrm{~kg}$ per bed and completely tilled. Slow-release fertilizer at $0.9 \mathrm{lb} / 1000 \mathrm{ft}^{2}$ nitrogen (equivalent to $227 \mathrm{~g}$ per bed) [14-16 months $18 \mathrm{~N}-2.6 \mathrm{P}-10 \mathrm{~K}$ (186-12) Osmocote ${ }^{\circledR}$ Lo-Start $^{\circledR}$; Scotts, Marysville, $\mathrm{OH}]$ was applied and tilled to provide additional nitrogen to maintain vegetative growth. Beds were covered with black weed barrier fabric (DeWitt Co., Sikeston, MO) to suppress weed growth.

Plant material and Shade TREATMENT. 'Celebrity' tomato and 'Sweet Banana' chili pepper plants were purchased from Peterson Brothers (San Antonio, TX) on 26 Mar. 2014. They were transplanted to l-gal plastic containers $[14.5 \mathrm{~cm}$ diameter, $13.5 \mathrm{~cm}$ height, and $2600 \mathrm{~cm}^{3}$ volume (PolyTainer No-1P; Nursery Supplies, Orange, CA)] filled with commercial medium (Metro-Mix 360; Sun Gro
Horticulture, Bellevue, WA). All plants were grown in a greenhouse and watered with nutrient solution which was prepared by adding $0.72 \mathrm{~g} \cdot \mathrm{L}^{-1} 15 \mathrm{~N}-2.2 \mathrm{P}-12.5 \mathrm{~K}$ (Peters 15-5-15, Scotts) to tap water. The electrical conductivity (EC) and $\mathrm{pH}$ of the nutrient solution were $1.4 \mathrm{dS} \cdot \mathrm{m}^{-1}$ and 6.4 , respectively. On 24 Apr. 2014, plants were transplanted to the field raised beds in two rows with a distance of $3 \mathrm{ft}$ between the two rows and $2 \mathrm{ft}$ between plants of the same row. Planting density was two plants per $10 \mathrm{ft}^{2}$. Plants were watered through a drip irrigation system twice daily at 7:00 AM and 1:00 PM (with about $\mathrm{l} \mathrm{L}$ each irrigation) except on rainy days. In addition, plants were hand watered with $2 \mathrm{~g} \cdot \mathrm{L}^{-1} 15 \mathrm{~N}-$ 2.2P-12.5K (Peters 15-5-15) solution (EC around $3.0 \mathrm{dS} \cdot \mathrm{m}^{-1} ; \mathrm{pH}$ around 6.2 ), $1 \mathrm{~L}$ per plant, once per week from 27 May to 8 July.

ENVIRONMENTAL CONDITIONS. Air and soil temperatures were measured every $30 \mathrm{~min}$ using type $\mathrm{T}$ copper-constantan thermocouples (Omega Engineering, Stamford, CT) connected to a datalogger (CR 1000; Campbell Scientific, Logan, UT). For air temperatures, three thermocouples per bed were placed at 20-inches aboveground to record ambient temperature. For soil temperatures, three thermocouples per bed were placed in the root zone of three randomly selected plants at 3 inches below the soil surface and at 4 inches away from the plant. $P P F$ was recorded every $30 \mathrm{~min}$ with a quantum sensor for each treatment (SP-110; Apogee Instruments, Logan, UT). Light sensors were placed at 2 -ft aboveground and $1.5 \mathrm{ft}$ below shadecloth. The daily light integral (DLI) was then calculated from the instantaneous PPF (Korczynski et al., 2002).

Plant growth AND FRUIT YIELD. Plant height and two perpendicular widths (width at the widest point and the other perpendicular width) were measured weekly (Hammond et al., 2007). Growth index was calculated as (height + width at the widest point + width perpendicular to the other width at the widest point $) \div 3$. These measurements were discontinued at the end of June for tomato because adjacent plants were touching each other. Marketable fruit was harvested weekly for both crops with first harvest dates of 27 May for chili and 9 June for tomato, and the number and fresh weight of fruit was recorded. In the middle of September, all plants were harvested for analysis. The marketable and unmarketable fruit were separated, and the number and fresh weight of fruit recorded. Shoot fresh weight was also recorded immediately. Due to limited oven space, all shoots were dried in a glass greenhouse at day temperatures ranging from 23 to $35^{\circ} \mathrm{C}$ for 2 weeks and dry weight was noted.

Physiological characteristics. Chlorophyll fluorescence and leaf temperature were taken at 10:00 $\mathrm{Am}$ and 2:00 PM in the middle of June, July, and August (a total of three replications). Chlorophyll fluorescence was determined with a chlorophyll fluorometer (pocket PEA; Hansatech Instruments, Norfolk, UK). Healthy and fully expanded leaves were chosen for the measurements, five plants per treatment per species. The leaves were dark acclimated for at least $30 \mathrm{~min}$ before $\mathrm{F}_{\mathrm{v}} / \mathrm{F}_{\mathrm{m}}$ measurements. Minimal fluorescence values in the dark-adapted state $\left(\mathrm{F}_{0}\right)$ were obtained by application of a low-intensity red measuring light source $(627 \mathrm{~nm})$, whereas maximal fluorescence values $\left(\mathrm{F}_{\mathrm{m}}\right)$ were measured after applying a saturating light pulse of $3500 \mu \mathrm{mol}^{-2} \cdot \mathrm{s}^{-1}$, and maximum quantum use efficiency of photosystem II (PS II) in the dark-adapted state was calculated as $\mathrm{F}_{\mathrm{v}} / \mathrm{F}_{\mathrm{m}}=\left(\mathrm{F}_{\mathrm{m}}-\mathrm{F}_{0}\right) / \mathrm{F}_{\mathrm{m}}$. Leaf temperatures were measured using an handheld infrared thermometer (OS530; Omega Engineering), five plants per treatment per species. The thermometer was pointed at a healthy and fully expanded leaf at a distance of $3 \mathrm{ft}$ (using a ruler).

Photosynthetic light responses were measured for tomato and chili pepper plants by using a portable photosynthesis system with an automatic universal PLC6 broad leaf cuvette (CIRAS-2; PP Systems International, Amesbury, MA). All plants were well watered before measurements. Healthy and fully expanded leaves of three plants per bed per species were chosen for the measurements. The carbon dioxide concentration within the leaf chamber was maintained at $375 \mu \mathrm{mol} \cdot \mathrm{mol}^{-1}$ when the photosynthetic light response curve was measured. Constant temperature $\left(25^{\circ} \mathrm{C}\right)$ and relative humidity $(50 \%)$ were maintained within the leaf cuvette during each measurement. Before each response curve was measured, 
the leaf clamped inside the leaf cuvette was exposed to a dark acclimation period of $30 \mathrm{~min}$. Light intensities $(P A R)$ were gradually increased from 0 to $2000 \mu \mathrm{mol} \cdot \mathrm{m}^{-2} \cdot \mathrm{s}^{-1}$ at $200 \mu \mathrm{mol} \cdot \mathrm{m}^{-2} \cdot \mathrm{s}^{-1}$ intervals. The minimum holding time between each step was $45 \mathrm{~s}$.

EXPERIMENTAL DESIGN AND STATISTICAL ANALYsis. The experiment was arranged in a split-plot design with shade treatment as the main plot and plant species as subplot with three replications. Shade treatment started on 12 May 2014 by installing the 7 -ft-wide black woven polypropylene cloth at $50 \%$ or $70 \%$ shade (Hummert International, Earth City, MO) over the raised beds. Metal fence posts were used to hold the shadecloth at $4 \mathrm{ft}$ aboveground. Both ends were also covered with the same shadecloth. One bed was considered as one replication for each shade level and there were five plants per species per bed, a total of 15 plants per species. For each species, an analysis of variance was conducted to test the influence of shade treatment on plant growth and physiological characteristics. Means separation among shade treatments was conducted using Tukey's honest significant difference multiple comparison when the shade treatment was significant. All statistical analyses were carried out using JMP (version 12; SAS Institute, Cary, NC). Polynomial regression model in SigmaPlot (version 13; Systat Software, San Jose, CA) was used to fit the photosynthetic light response data.

\section{Results and discussion}

ENVIRONMENTAL PARAMETERS. Air temperatures were higher in full sun treatment at all measurement dates compared with $50 \%$ and $70 \%$ shade (Fig. 1). The difference in air temperatures was as high as (mean $\pm \mathrm{SD}$ ) $1.1 \pm$ $0.3{ }^{\circ} \mathrm{C}$ for $50 \%$ shade and $0.9 \pm 0.3{ }^{\circ} \mathrm{C}$ for $70 \%$ shade. Air temperatures did not differ between $50 \%$ and $70 \%$ during the duration of this study. Kittas et al. (2009) found that the reduction of solar radiation above the crop was proportional to the shading intensity of the net and the canopy temperature was significantly lower under the shading nets than in the open field. LopezMarin et al. (2012) noted a large difference between the unshaded control and the greenhouses shaded by screen. This difference was as high as $5.2^{\circ} \mathrm{C}$ under $60 \%$ shade and $4.1^{\circ} \mathrm{C}$ under $40 \%$ shade. Similar results were obtained by Beppu and Kataoka (2000) who reported a 1.9 and $3.3^{\circ} \mathrm{C}$ reduction in daily maximum air temperatures with shading levels of $53 \%$ and $78 \%$, respectively.

We observed similar trends in soil temperature measurements with full sun treatment having the highest soil temperatures compared with $50 \%$ and $70 \%$ shade. Soil temperature in full sun treatment was about $2.4 \pm$ $0.6{ }^{\circ} \mathrm{C}$ higher than $50 \%$ shade and $3.0 \pm 0.7{ }^{\circ} \mathrm{C}$ higher than $70 \%$ shade. No apparent differences were observed for soil temperature measurements between $50 \%$ and $70 \%$ shade. Lower soil temperatures mean lower evaporation rates which lead to less moisture loss.

The average DLI, which is the total amount of light received in a single day, was between $20.4 \pm 3.4$ and $12.1 \pm 1.2 \mathrm{~mol} \cdot \mathrm{m}^{-2} \cdot \mathrm{d}^{-1}$ for the $50 \%$ and $70 \%$ shade treatments, respectively, and $52.5 \pm 8.9 \mathrm{~mol} \cdot \mathrm{m}^{-2} \cdot \mathrm{d}^{-1}$ for full sun. In reality, the $50 \%$ and $70 \%$ shade treatment reduced DLI $60 \%$ and $77 \%$ compared with full sun.
FRUIT YIELD AND GROWTH. In general, tomato and chili pepper yield (number and fresh weight of marketable fruit) and potential yield (number and fresh weight of unmarketable fruit) were numerically the highest for plants grown in full sun, with the exception of fresh weight of marketable tomato fruit (Table 1 ). The number and fresh weight of marketable tomatoes at $50 \%$ shade was not statistically different from the control, while those of unmarketable fruit were significantly lower. Tomato plants grown at $70 \%$ shade had significantly lower yield of both marketable and unmarketable fruit compared with the full sun control. Tomato plants grown at $70 \%$ shade were also significantly lower than $50 \%$ shade treatment for marketable fruit but not for unmarketable fruit.

El-Gizawy et al. (1992) reported an increase in total production with the use of shading up to $51 \%$ and the highest tomato yield obtained under $35 \%$ shading. Fresh weight of tomato shoots was not statistically different among all treatments; however, dry
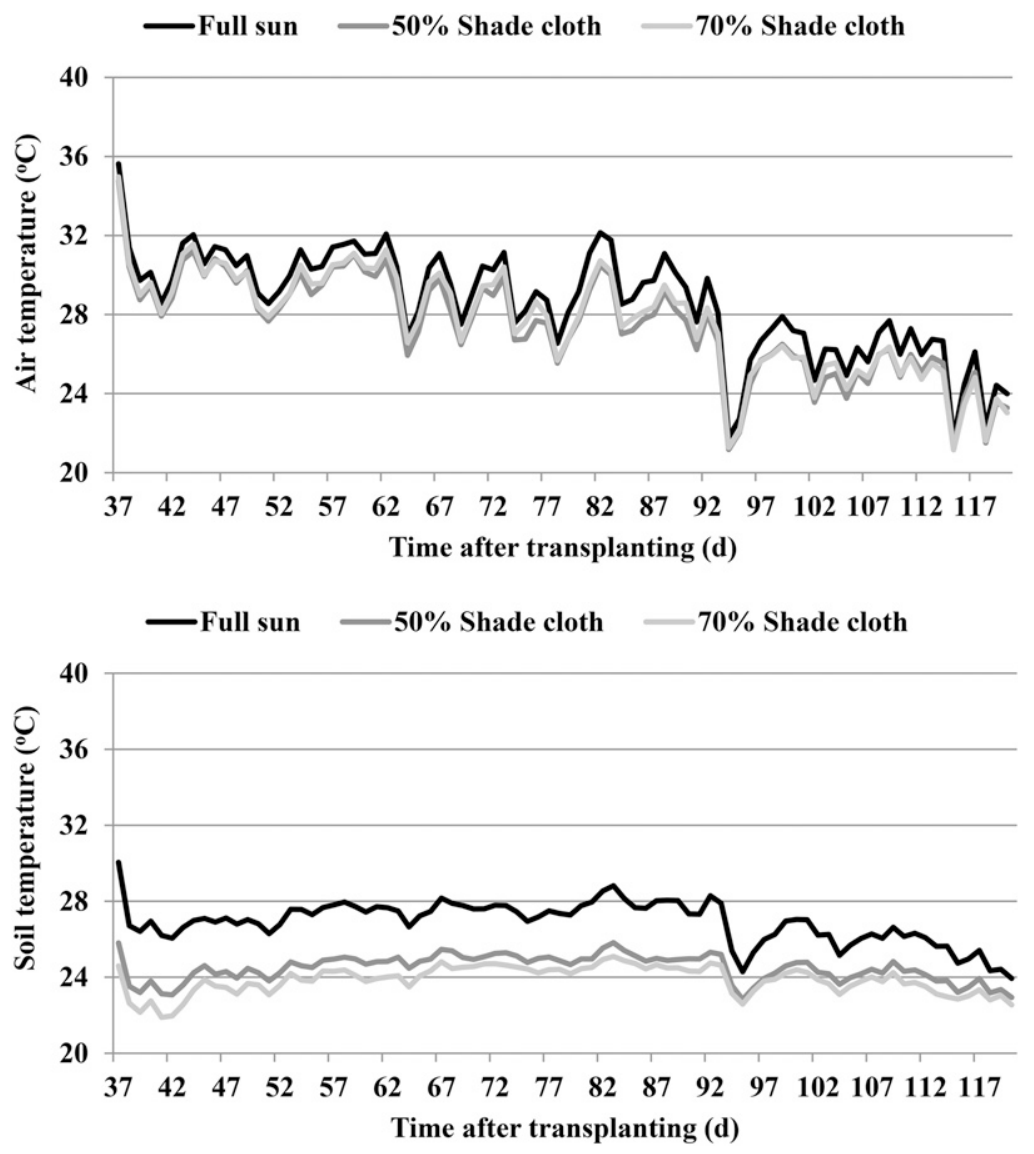

Fig. 1. Air and soil temperatures measured at $50 \%$ shadecloth, $70 \%$ shadecloth, and full sun from June to Aug. $2014 ;\left(1.8 \times{ }^{\circ} \mathrm{C}\right)+32={ }^{\circ} \mathrm{F}$. 
Table 1. Accumulated number and fresh weight of marketable and unmarketable fruit over the season and FW and dry weight of shoots of tomato and chili pepper plants at the end of experiment grown under $50 \%$ shadecloth, $70 \%$ shadecloth, and full sun in a field experiment with three replications and five plants per replication.

\begin{tabular}{|c|c|c|c|c|c|c|c|}
\hline \multirow[b]{2}{*}{ Treatment } & \multicolumn{3}{|c|}{ Marketable fruit } & \multicolumn{2}{|c|}{ Unmarketable fruit } & \multirow[b]{2}{*}{ Shoot fresh wt $(\mathrm{g})$} & \multirow[b]{2}{*}{ Shoot dry wt (g) } \\
\hline & Fruit (no.) & Fresh wt $(\mathrm{g})^{\mathrm{z}}$ & Avg fresh wt (g) & Fruit (no.) & Fresh wt (g) & & \\
\hline \multicolumn{8}{|l|}{ Tomato } \\
\hline $70 \%$ shadecloth & $7.2 \mathrm{~b}$ & $559.6 \mathrm{~b}$ & $63.1 \mathrm{~b}$ & $5.0 \mathrm{~b}$ & $184.0 \mathrm{~b}$ & $2,997.0 \mathrm{a}$ & $412.9 \mathrm{~b}$ \\
\hline Full sun & $22.6 \mathrm{a}$ & $1,160.5 \mathrm{a}$ & $89.9 \mathrm{a}$ & $27.0 \mathrm{a}$ & $1,320.9 \mathrm{a}$ & $3,630.0 \mathrm{a}$ & $600.3 \mathrm{a}$ \\
\hline \multicolumn{8}{|l|}{ Chili pepper } \\
\hline Full sun & $167.4 \mathrm{a}$ & $2,195.2 \mathrm{a}$ & $18.1 \mathrm{a}$ & $14.4 \mathrm{a}$ & $152.1 \mathrm{a}$ & $485.0 \mathrm{a}$ & $102.2 \mathrm{a}$ \\
\hline
\end{tabular}

${ }^{\mathrm{z}} 1 \mathrm{~g}=0.0353 \mathrm{oz}$.

${ }^{y}$ Means with same lowercase letters within columns are not significantly different among treatments by Tukey's honest significant difference multiple comparison at $P<0.05$.

weight was lower at $70 \%$ shade compared with the unshaded control. Kittas et al. (2009) found that shading $(34 \%$ to $50 \%)$ increased total marketable yield production, reduced the appearance of tomato cracking about $50 \%$ and, accordingly, the marketable tomato production was about $50 \%$ higher under shading conditions than under nonshading conditions. El-Aidy and El-Afry (1983) observed the highest tomato yields with $40 \%$ shading and concluded that increasing shading intensity over $40 \%$ does not increase crop production. Aberkani et al. (2008) observed that fruit yield was numerically higher in the shaded treatment, but not statistically different from the unshaded control. However, fruit number and marketable yield were statistically higher. Kittas et al. (2012) studied the effect of four shade nets with different shading intensities (34\% to $49 \%)$ and reported that the total dry matter of tomato was not decreased. Ideally, a movable shade structure works the best. On raining days or in early mornings when the temperature and light intensity are not too high, shading should be removed. However, this would increase labor cost. Mobile shading improved the quality of tomato and increased marketable yield of cucumber [Cucumis sativus (Lorenzo et al., 2006)].

Chili pepper yield grown at $50 \%$ shade did not differ statistically from the full sun control except for number of marketable fruit (Table 1). However, $70 \%$ shade resulted in significantly lower yields of marketable fruit compared with full sun. The two shade treatments did not differ statistically for all measured growth and yield traits except for fresh weight of
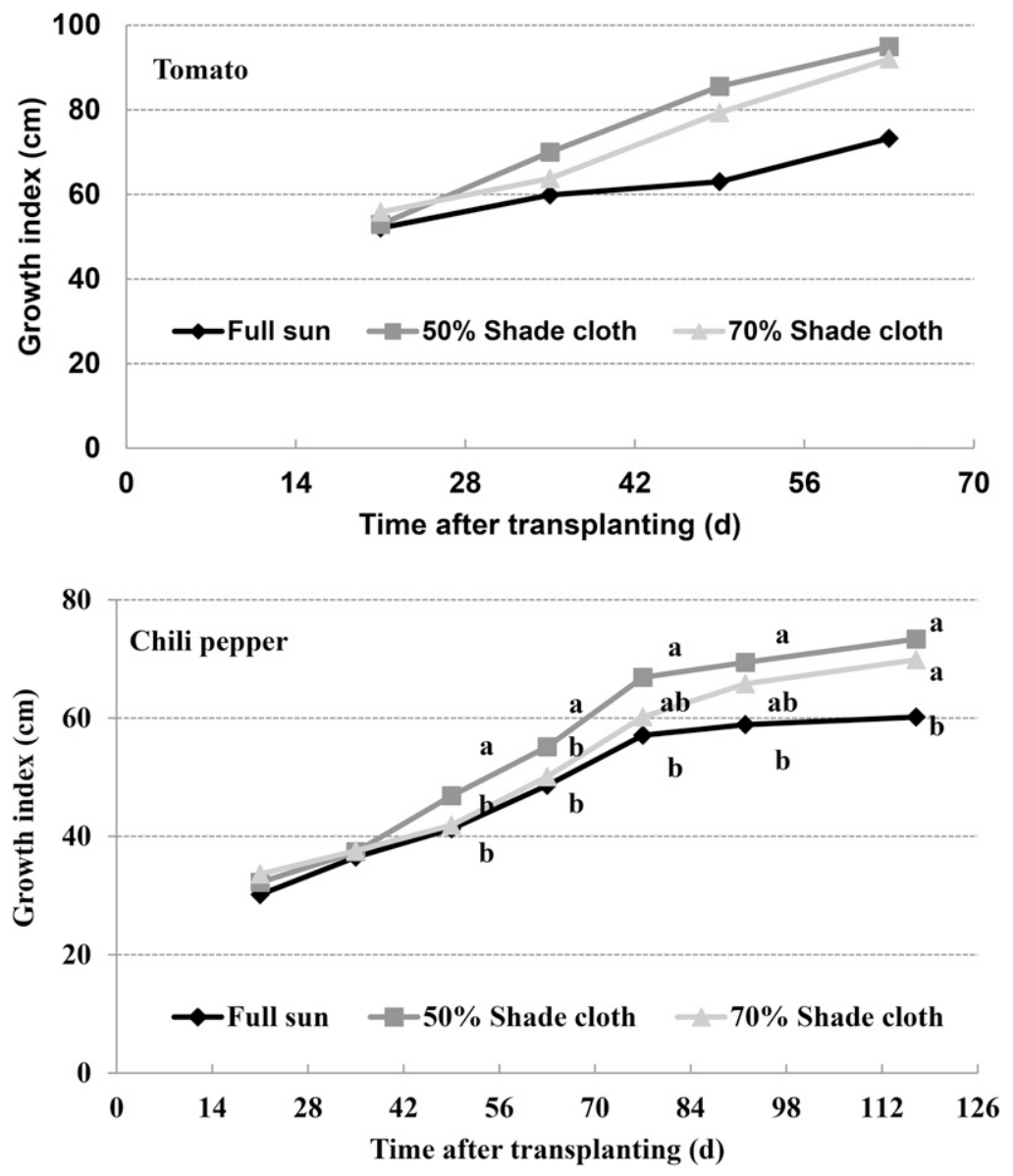

Fig. 2. Growth index of tomato and chili pepper plants measured at $50 \%$ shadecloth, 70\% shadecloth, and full sun from May to Aug. 2014. Means with same lowercase letters on the same date are not significantly different among treatments by Tukey's honest significant difference multiple comparison at $P<0.05$; $1 \mathrm{~cm}=0.3937$ inch .

marketable fruit. No differences were observed for fresh and dry weight of shoots of chili pepper at all shade levels. In contrast, Lopez-Marin et al. (2012) determined that chili pepper plants grown under $40 \%$ shade yielded $1.26 \mathrm{~kg} \cdot \mathrm{m}^{-2}$ more than control; however, yields of $60 \%$ shade and control treatment were similar. Rylski and Spigelman (1986) obtained similar results. Santana et al. (2012) evaluated the effect of red and blue screens (both at $40 \%$ shade rating) on chili pepper. The authors observed that blue and red screens reduced yield of chili pepper compared with field conditions 
Table 2. Chlorophyll fluorescence $\left(\mathrm{F}_{\mathrm{v}} / \mathrm{F}_{\mathrm{m}}\right)$ of tomato and chili pepper plants grown at $50 \%$ shadecloth, $70 \%$ shadecloth, and full sun measured at 10:00 $\mathrm{AM}(\mathrm{AM})$ and 2:00 РM (PM) between June and Aug. 2014.

\begin{tabular}{|c|c|c|c|c|c|c|}
\hline \multirow[b]{3}{*}{ Treatment } & \multicolumn{6}{|c|}{$\mathrm{F}_{\mathrm{v}} / \mathrm{F}_{\mathrm{m}}$} \\
\hline & \multicolumn{2}{|c|}{ June } & \multicolumn{2}{|c|}{ July } & \multicolumn{2}{|c|}{ August } \\
\hline & AM & PM & $\mathrm{AM}$ & $\mathbf{P M}$ & AM & PM \\
\hline $50 \%$ shadecloth & $0.81 \mathrm{a}^{\mathrm{z}}$ & $0.72 \mathrm{a}$ & $0.81 \mathrm{a}$ & $0.75 \mathrm{a}$ & $0.81 \mathrm{a}$ & $0.75 \mathrm{a}$ \\
\hline $70 \%$ shadecloth & $0.82 \mathrm{a}$ & $0.75 \mathrm{a}$ & $0.81 \mathrm{a}$ & $0.75 \mathrm{a}$ & $0.81 \mathrm{a}$ & $0.75 \mathrm{a}$ \\
\hline Full sun & $0.70 \mathrm{~b}$ & $0.51 \mathrm{~b}$ & $0.76 \mathrm{~b}$ & $0.65 \mathrm{~b}$ & $0.76 \mathrm{~b}$ & $0.65 \mathrm{~b}$ \\
\hline $70 \%$ shadecloth & $0.81 \mathrm{a}$ & $0.77 \mathrm{a}$ & $0.81 \mathrm{a}$ & $0.75 \mathrm{a}$ & $0.81 \mathrm{a}$ & $0.75 \mathrm{a}$ \\
\hline Full sun & $0.71 \mathrm{~b}$ & $0.61 \mathrm{~b}$ & $0.76 \mathrm{~b}$ & $0.70 \mathrm{~b}$ & $0.76 \mathrm{~b}$ & $0.70 \mathrm{~b}$ \\
\hline
\end{tabular}

$P<0.05$.

and that red screen had higher yields than blue screen. However, the authors observed that fruit weight was higher in blue screen than red and field conditions which did not differ. In our trial, black shadecloth at $50 \%$ resulted in similar yields to full sun conditions. It appears that shadecloth color plays an important role on yield, not just the shade rating.

Tomato and chili pepper plants grown in full sun generally had the lowest growth index throughout the growing season compared with the two shade treatments (Fig. 2). No difference in growth index was found for tomato plants between the two shade treatments. Similar results were observed for chili plants in growth index after 24 June. By 1 July when measurements for tomato plants were ended, plants were 95 and $92 \mathrm{~cm}$ in height for $50 \%$ and $70 \%$ shade treatments, respectively, compared with $73 \mathrm{~cm}$ for those in full sun. On the other hand, chili pepper plants grown in full sun averaged $60 \mathrm{~cm}$ in height by 14 Aug. compared with 73 and $70 \mathrm{~cm}$ for $50 \%$ and $70 \%$ shade treatments, respectively. Both tomato and chili pepper plants had the highest growth index with $50 \%$ shade, the lowest with full sun, and an intermediate growth index with $70 \%$ shade.

There were no differences in fresh weight of shoots for both tomato and chili pepper plants (Table 1). No differences in dry weight of shoots were found among treatments for chili pepper, while that of tomato plants grown under $70 \%$ shade was the lowest. No statistical difference was found in dry weight of shoots in tomato plants between $50 \%$ shade and full sun.

Chlorophyll fluorescence. $\mathrm{F}_{\mathrm{v}} / \mathrm{F}_{\mathrm{m}}$ was significantly lower for
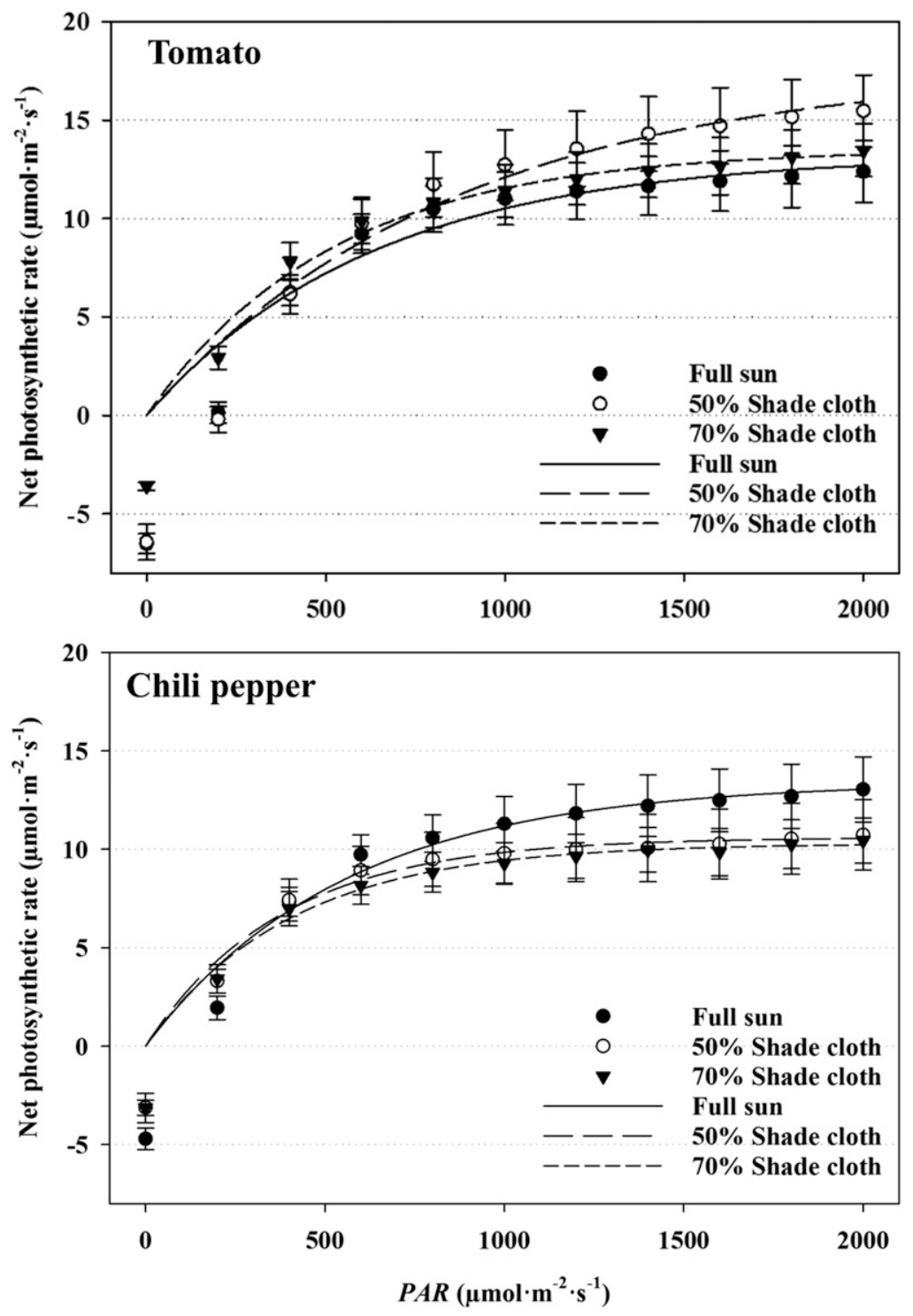

Fig. 3. Net photosynthetic rates in response to light intensity (light response curves) of tomato and chili pepper plants grown at $50 \%$ shadecloth, $70 \%$ shadecloth, and full sun [photosynthetically active radiation $(P A R)$ ]. Polynomial regression model was used to fit the photosynthetic light response data. Error bars represent SE of nine measurements. 
Table 3. Leaf temperatures measured by an infrared thermometer of tomato and chili pepper plants grown at $50 \%$ shadecloth, 70\% shadecloth, and full sun measured at 10:00 АM (AM) and 2:00 РM (PM) between June and Aug. 2014.

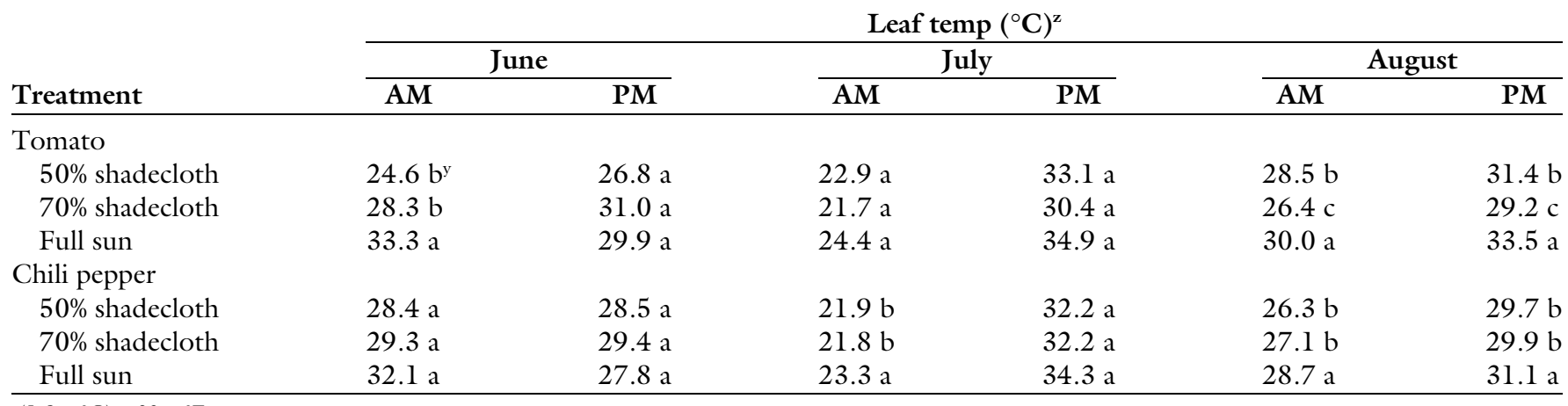

${ }^{\mathrm{z}}\left(1.8 \times{ }^{\circ} \mathrm{C}\right)+32={ }^{\circ} \mathrm{F}$.

${ }^{y}$ Means with same lowercase letters within columns are not significantly different among treatments by Tukey's honest significant difference multiple comparison at $P<0.05$.

tomato plants grown in full sun when measured in June, July, and August (Table 2) indicating plants were more stressed. Lower $\mathrm{F}_{\mathrm{v}} / \mathrm{F}_{\mathrm{m}}(<0.8)$ indicates higher stress to the photosynthetic process, which was observed in plants grown in full sun (Maxwell and Johnson, 2000). No significant differences in $\mathrm{F}_{\mathrm{v}} / \mathrm{F}_{\mathrm{m}}$ were observed between $50 \%$ and $70 \%$ shade treatments. Aberkani et al. (2008) observed higher $\mathrm{F}_{\mathrm{v}} / \mathrm{F}_{\mathrm{m}}$ values in late summer in tomato plants in a foam shaded greenhouse and concluded that unshaded plants were more stressed.

Chili pepper also had higher and statistically different $F_{v} / F_{m}$ values for $50 \%$ and $70 \%$ shade compared with full sun. One notable exception was observed in July and August when $\mathrm{F}_{\mathrm{v}} / \mathrm{F}_{\mathrm{m}}$ measured in the afternoon of chili pepper at $50 \%$ shade was not statistically different from full sun (Table 2).

Response of $\boldsymbol{P}_{\mathrm{N}}$ TO Light INTENSITY. Light response curves indicate the potential photosynthetic ability of the plants. The maximum $P_{n}$ indicates the maximum potential $P_{n}$ at light saturation point. Maximum $P_{n}$ of tomato plants was lowest for the plants grown under full sun with a peak at $12.4 \mu \mathrm{mol} \cdot \mathrm{m}^{-2} \cdot \mathrm{s}^{-1}$ and highest with $50 \%$ shade with a peak at $15.5 \mu \mathrm{mol} \cdot \mathrm{m}^{-2} \cdot \mathrm{s}^{-1}$ at $2000 \mu \mathrm{mol} \cdot \mathrm{m}^{-2} \cdot \mathrm{s}^{-1}$ (Fig. 3). Tomato plants grown in $70 \%$ shade had a photosynthetic response curve similar to that of full sun. Aberkani et al. (2008) evaluated foam shading (40\% to $65 \%$ shade) and observed slightly higher light response curves of tomato compared with unshaded control early in the summer.

Chili pepper, on the other hand, had a different photosynthetic response curve whereby plants grown in full sun had the highest $P_{n}$ at light saturation point (maximum of $13.0 \mu \mathrm{mol} \cdot \mathrm{m}^{-2} \cdot \mathrm{s}^{-1}$ ), while $50 \%$ and $70 \%$ shade had almost identical response curve with a maximum of $10 \mu \mathrm{mol} \cdot \mathrm{m}^{-2} \cdot \mathrm{s}^{-1}$ (Fig. 3). These results may indicate that tomato plants grown in the $50 \%$ and chili plants grown at full sun have greater photosynthetic capacity compared with other treatments, although the differences were small, especially at lower light intensities. These results may indicate that chili pepper plants could yield the highest biomass, which coincided with dry weight of shoots and fruit yield, and possibly the highest fruit yield under full sun.

Katsoulas et al. (2012) evaluated two insect-proof white nets (13\% and $34 \%$ shading) and observed no reduction in photosynthesis in chili pepper despite a substantial difference in incident light regimen. Unshaded open field and $13 \%$ shade white nets had similar rates of photosynthesis and significantly higher than $34 \%$ shade. In a study on chili pepper cultivated under $40 \%$ and $60 \%$ shade, Lopez-Marin et al. (2012) observed that the maximum daily $P A R$ decreased to 580 and $220 \mu \mathrm{mol} \cdot \mathrm{m}^{-2} \cdot \mathrm{s}^{-1}$, respectively, compared with the unshaded control.

LEAF TEMPERATURe. Leaf temperature generally did not differ among all treatments and crops except for early in the season (morning in June for tomato) and late in season (August for tomato and chili pepper) (Table $3)$. In August, leaf temperatures were the highest in plants grown in full sun and the lowest in $70 \%$ shade. Seventy percent shade was statistically different from $50 \%$ shade for tomato, but not for chili pepper. Similar results were observed by Smith et al. (1984) in greenhouse tomato and cucumber and by Raveh et al. (2003) in Murcott tangor (Citrus reticulata $\times$ Citrus sinensis).

Based on the 1-year results of measured DLI, and growth and physiological parameters, we conclude that $70 \%$ shade was too much shade for tomato and chili pepper and that a $50 \%$ shade treatment resulted in higher growth index in both crops. Although $50 \%$ shade is suitable to alleviate heat stress and to maintain similar yield, a lower shade percentage may be more effective to maximize yield and productivity. Further study is needed to determine the best shading intensity.

\section{Literature cited}

Aberkani, K., X. Hao, A. Gosselin, and D. de Halleux. 2008. Responses of leaf gas exchanges, chlorophyll a fluorescence, and fruit yield and quality of greenhouse tomato to shading with retractable liquid foam. Acta Hort. 797:235-240.

Beppu, K. and I. Kataoka. 2000. Artificial shading reduces the occurrence of double pistils in 'Satohnishiki' sweet cherry. Scientia Hort. 83:241-247.

Dorji, K., M.H. Behboudiana, and J.A. Zegbe-Domínguez. 2005. Water relations, growth, yield, and fruit quality of hot pepper under deficit irrigation and partial rootzone drying. Scientia Hort. 104:137-149.

El-Aidy, F. and M. El-Afry. 1983. Influence of shade on growth and yield of tomato cultivated during the summer season in Egypt. Plasticulture 47:2-6.

El-Gizawy, A.M., M.M.F. Abdallah, H.M. Gomaa, and S.S. Mohamed. 1992. Effect of different shading levels on tomato 
plants 2 . Yield and fruit quality. Acta Hort. 323:349-354.

Hammond, H.E., R.K. Schoellhorn, S.B. Wilson, and J.G. Norcini. 2007. Differing blanketflower cultivar and ecotype responses to plant growth regulators. HortTechnology 17:552-556.

Katsoulas, N., A. Kandila, E. Kitta, and A. Baille. 2012. Transpiration and photosynthesis of sweet pepper growing under differing screenhouse nets. Acta Hort. 956:539-544.

Katsoulas, N. and C. Kittas. 2008. Impact of greenhouse microclimate on plant growth and development with special reference to the Solanaceae. European J. Plant Sci. Biotechnol. 2(special issue $1): 31-44$.

Kittas, C., N. Katsoulas, N. Rigakis, T. Bartzanas, and E. Kitta. 2012. Effects on microclimate, crop production, and quality of a tomato crop grown under shade nets. J. Hort. Sci. Biotechnol. 87: 7-12.

Kittas, C., N. Rigakis, N. Katsoulas, and T. Bartzanas. 2009. Influence of shading screens on microclimate, growth, and productivity of tomato. Acta Hort. 807:97-102.

Korczynski, P.C., J. Logan, and J.E. Faust. 2002. Mapping monthly distribution of daily light integrals across the contiguous United States. HortTechnology 12:12-16.

LeBoeuf, J. 2004. Effects of high and low temperatures on tomato and pepper crop.
8 Dec. $2015 .<$ http://xtremehorticulture. blogspot.com/2013/05/effect-of-highand-low-temperatures-on.html>.

Lopez-Marin, J., A. Galvez, A. Gonzalez, C. Egea-Gilabert, and J.A. Fernandez. 2012. Effect of shade on yield, quality, and photosynthesis-related parameters of sweet pepper plants. Acta Hort. 956:545552.

Lopez-Marin, J., A. Galvez, and A. Gonzalez. 2011. Effect of shade on quality of greenhouse peppers. Acta Hort. 893:895-900.

Lorenzo, P., M.L. Garcia, M.C. SanchezGuerro, E. Medrano, I. Caparros, and M. Giménez. 2006. Influence of mobile shading on yield, crop transpiration and water use efficiency. Acta Hort. 719:471478 .

Maxwell, K. and G. Johnson. 2000. Chlorophyll fluorescence: A practical guide. J. Expt. Bot. 51:659-668.

Rajapakse, N.C. and Y. Shahak. 2007. Light quality manipulation by horticulture industry, p. 290-312. In: G. Whitelam and K. Halliday (eds.). Light and plant development. Blackwell Publ., Oxford, UK.

Raveh, E., S. Cohen, T. Raz, D. Yakir, A. Grava, and E.E. Goldschmidt. 2003. Increased growth of young citrus trees under reduced radiation load in a semi-arid climate. J. Expt. Bot. 54:365-373.

Rylski, I. and M. Spigelman. 1986. Effect of shading on plant development, yield, and fruit quality of sweet pepper grown under conditions of high temperature and radiation. Scientia Hort. 29:31-35.

Santana, J.Q., M.A. Balbino, T.R. Tavares, R.S. Bezerra, J.G. Farias, and R.C. Ferreira. 2012. Effect of photosynthetic screens in the development and productivity of red and yellow sweet pepper. Acta Hort. 956:493-500.

Shahak, Y., K. Ratner, Y.E. Giller, N. Zur, E. Or, E.E. Gussakovsky, R. Stern, P. Sarig, E. Raban, E. Harcavi, I. Doron, and Y. Greenblat-Avron. 2008. Improving solar energy utilization, productivity, and fruit quality in orchards and vineyards by photoselective netting. Acta Hort. 772:65-72.

Smith, I.E., M.J. Savage, and P. Mills. 1984. Shading effects on greenhouse tomato and cucumber. Acta Hort. 148:229237.

Tanny, J., M. Pirkner, M. Teitel, S. Cohen, Y. Shahak, O. Shapira, and Y. Israeli. 2014. The effect of screen texture on air flow and radiation transmittance: Laboratory and field experiments. Acta Hort. 1015:45-51.

U.S. Department of Agriculture. 1971. Soil survey, El Paso County, Texas. U.S. Dept. Agr., Soil Conservation Serv. and Texas Agr. Expt. Sta., Washington, DC. 